\section{Sobre el uso historiográfico del concepto de región}

José Carlos Chiaramonte
José Carlos Chiaramonte es Investigador del CONICET, Director del Instituto de Historia Argentina y Americana «Dr. Emilio Ravignani» de la Facultad de Filosofía y Letras de la Universidad de Buenos Aires, y Profesor Honorario de esa universidad.

25 de Mayo 221, $2^{\circ}$ piso, (1002) Capital Federal

Tel/Fax 43420983.

e-mail: chiaramo@mail.retina.ar

e-mail: ravigna@mail.retina.ar

\section{Resumen}

Las infructuosas tentativas de definir el concepto de región provienen de supuestos inconscientes que han convertido el vocablo en un cliché, carente de real sustancia histórica. Esto es notorio en la historia económica, cuando se parte de la supuesta correspondencia entre un espacio natural definido -como el de una región geográfica- y un conjunto de actividades económicas. Como no ha sido posible establecer una relación de ese tipo entre la supuesta economía regional y la región natural, el criterio predominante es que no existe una región verdadera, sino tantas regiones como objetivos de estudio se tengan.

Sin embargo, hay otro uso, peculiar de los historiadores, que concierne a la historia en su conjunto, no sólo a la historia económica, pues la noción de región evoca, en realidad, una perspectiva de historia total. Una perspectiva según la cual, además, una región lo es cuando tiene presencia histórica, en la historia global de un país. Aquí también, el peso inconsciente de este supuesto y el uso no crítico del término, contaminan las investigaciones de los historiadores, que multiplican regiones en realidad inexistentes utilizando un concepto carente de real sustancia histórica, que proviene del uso irreflexivo del vocabulario utilizado.
Este texto es una reelaboración de la ponencia presentada en el I Simposio Argentino-Chileno de Historia Regional, Universidad Nacional de la Patagonia, San Juan Bosco, Sede Ushuaia/Consulado de Chile en Ushuaia; Ushuaia, 15 de septiembre de 1998. El autor agradece la valiosa asistencia de Nora Souto en la búsqueda de información y en la crítica de los primeros borradores del texto, así como las observaciones efectuadas al mismo por Fernando Devoto, Jorge Gelman y Eduardo Míguez.

\section{Summary}

The unsuccessful attempts to define the concept of «region» had come from unconscious assumptions that have turned the word into a cliché, without real historical substance. This is well known in economic history, particularly when the starting point is the alleged correspondence between a natural space -defined as a geographical region- and a set of economic activities. As has not been possible to establish such a relationship between the alleged regional economy and the natural region, the overriding criterion is that there is no «real» region, but as many regions as objects of study are taken.

However, there is another use, peculiar to historians, concerning the history as a whole, not just economic history. The "region» concept evokes, actually, a total history perspective. According to that perspective, a region exists when it has a historic presence in the global history of a specific country. Here, too, the unconscious weight of this concept and the non-critical use of it, pollute the work of the historians, which disseminate everywhere nonexistent regions, using a concept without real historical substance, based on an unthinking use of the word. 